\title{
ДОСВІД ВИКЛАДАННЯ ЕЛЕКТИВНОГО КУРСУ “МЕДИЧНІ АПАРАТИ І СИСТЕМИ” ДЛЯ СУБОРДИНАТОРІВ МЕДИЧНОГО ФАКУЛЬТЕТУ
}

В. М. Творко, І. О. Боровик

ДВНЗ “Тернопільський державний медичний університет імені І. Я. Горбачевського МОЗ Украйни”

\section{EXPERIENCE OF TEACHING ELECTIVE COURSES "MEDICAL APPARATUS AND SYSTEMS” FOR STUDENTS OF THE 6-TH COURSE OF MEDICAL FACULTY}

\author{
V. M. Tvorko, I. O. Borovyk \\ SHEI "Ternopil State Medical University by I. Ya. Horbachevsky of MPH of Ukraine"
}

\begin{abstract}
У статті представлено дані про викладання елективного курсу "Медичні апарати і системи" на 6 курсі медичного факультету. Особливістю практичних занять є використання сучасних комп'ютерних технологій, подання світових даних та власного клінічного досвіду викладача для досягнення основної мети - формування клінічного мислення у майбутніх лікарів.
\end{abstract}

The paper presents data on the teaching of elective courses "Medical Apparatus and Systems" on the 6 th course of medical faculty. The specificity of practical lessons is the use of modern computer technologies, presentation of world information and own clinical experience of the lecturer for achievement of the main purpose - forming of clinical thought in future doctors.

Вступ. Науково-технічний прогрес в медичній галузі передбачає пошук і широке впровадження новітніх технологій в клінічній практиці, вимагає постійного вдосконалення знань, необхідних для ефективного використання можливостей технічних досягнень. Останні повинні забезпечити прорив у сфері діагностики, профілактики і лікування захворювань на принципах доказової медицини [1]. Це вимагає поглибленого вивчення принципів роботи сучасної медичної апаратури, іiі діагностичних можливостей, що безпосередньо вплине на якість лікувально-діагностичного процесу.

Основна частина. Студенти першого курсу медичного факультету, вивчаючи медичну та біологічну фізику, мають змогу ознайомитись 3 теоретичними основами електрокардіографії, застосуванням рентгенівського випромінювання та явища ядерномагнітного резонансу в медицині.

Протягом навчання на клінічних кафедрах студенти знайомляться з сучасною діагностичною і лікувальною медичною технікою та апаратурою [2], проте цілісної уяви про функціонування і можливості більшості апаратів у них немає. Щоб узагальнити ці знання і вміння, виникла необхідність створити для студентів 6 курсу на кафедрі поліклінічної справи та сімейної медицини елективний курс "Медичні апа- рати і системи". Викладачами кафедри було розроблено робочі програми курсу (для вітчизняних і зарубіжних студентів), якими передбачались лекції, практичні заняття, години на самостійну роботу. Досвід перших років викладання підтвердив, що найбільш ефективною формою оволодіння матеріалом $€$ практичні заняття, тому в подальшому в робочій програмі і відповідно у навчальному плані були залишені практичні заняття і самостійна робота. В даний час згідно з засадами Болонської системи навчальним планом на викладання курсу "Медичні апарати і системи" на 6-му році навчання відводиться 1,8 кредиту, тобто 54 години, з яких аудиторних (практичних занять) 21 година і 33 години - самостійна робота студентів. Дисципліна структурована на 1 модуль, який включає 3 змістовних модулі.

Змістовний модуль “Основні принципи роботи електрокардіографів. Техніка запису ЕКГ та ії діагностичні можливості. Холтерівський моніторинг ЕКГ" передбачає узагальнення знань щодо принципу роботи електрокардіографа і практичні навики техніки запису ЕКГ. Ознайомлення з роботою електрокардіографічного комплексу “CARDIO” і сучасними добовими моніторами артеріального тиску. Субординатори розглядають структуру сучасних кардіографів, готують апарат до роботи, розміщують електроди

(C) В. М. Творко, І. О. Боровик 
на тілі пацієнта у стандартних відведеннях, проводять запис і попередній аналіз ЕКГ, знайомляться 3 роботою програмно-апаратного комплексу автоматизованого аналізу ЕКГ УСЕКГ -01 “CARDIO”, ЮКАРД 100, $з$ можливістю передачі даних через GSM модуль або через Інтернет.

У процесі заняття наголошується, що однією з актуальних проблем сучасної кардіології залишається отримання максимально повної інформації про електричний потенціал серця, на підставі якої можна було б розширити діагностику патологічних станів міокарда, його електрофізіологічних властивостей. Широкий розвиток комп'ютерних технологій, сучасних методів цифрової обробки даних та існуючі клінічні завдання зумовили розробку і широке використання в повсякденній практиці комп'ютерних електрокардіографічних систем.

Найбільш істотне підвищення точності оцінки стану серця забезпечує електрокардіографічне картування, що передбачає визначення електричного потенціалу на всій поверхні тіла шляхом синхронної реєстрації сигналів множинних відведень, розподілених на цій поверхні. При ЕКГ-картуванні обсяг вихідної інформації істотно більший, ніж при використанні загальноприйнятих електрокардіографічних методів, причому відкриваються можливості більш детального і глибокого аналізу даних вимірювань.

Змістовний модуль “Принципи роботи рентгенапаратури. Показання та протипоказання до рентгенообстежень. Принципи роботи комп'ютерних та магніторезонансних томографів. Показання та протипоказання до виконання комп'ютерної і магніторезонансної томографії. Принципи підготовки хворих до обстеження. Діагностичні можливості”. Випускники збирають анамнез, проводять об' єктивне обстеження хворого, призначають необхідний обсяг параклінічних досліджень і беруть участь у проведенні рентгенологічного обстеження, оцінюють результати рентгенограм.

Важливим в роботі лікаря є правильний вибір при призначенні додаткових методів обстеження. Під час практичного заняття на базі лікарні студенти мають можливість ознайомитись 3 принципом роботи комп'ютерного і магніторезонансного томографів, які дають змогу отримати високоякісні зображення органів людського тіла. Звертається особлива увага на загальні показання та протипоказання до проведення обстежень, на підготовку та процедуру проведення маніпуляцій. Розглядаються питання переваги того чи іншого дослідження перед іншим методом та вартості апаратури а, відповідно, і дослідження.
Змістовний модуль “Принципи роботи апаратури для УЗД-досліджень. Особливості підготовки і проведення досліджень. Діагностичні можливості. Принципи виконання ехокардіоскопіі, доплерографіі. Показання до виконання. Діагностичні можливості". Студенти знайомляться з апаратурою для УЗД-досліджень, ехокардіоскопії, доплерографії, беруть участь в підготовці хворого і проведенні досліджень, аналізують їх результати.

На занятті акцентується увага, що нове покоління У3-сканерів дозволило ультразвуковій діагностиці вийти на абсолютно новий якісний рівень, що, в свою чергу, вимагає від лікарів нових підходів і знань. Одним 3 таких ультразвукових приладів нового покоління $є$ універсальна ультразвукова цифрова система вищого класу SSD-3500 фірми "ALOKA", яку можна застосовувати для дослідження абдомінальних органів, поверхневих органів, кардіологіі, урології, ангіології, акушерства та гінекологіі. Ультразвукове дослідження завдяки своїй високій інформативності, неінвазивності, швидкості виконання, можливості багаторазового повторення без шкоди для здоров'я пацієнта займає одне 3 провідних місць серед інших методів дослідження. Сьогодні ультразвук, безперечно, вважається методом пошуку і досить часто методом вибору в діагностиці захворювань. 3 впровадженням нових комп'ютерних технологій діагностичні можливості ультразвукового методу збагатилися. У клінічну практику увійшли нові методики дослідження: енергетичний доплер, тривимірна і панорамна ехографія, безконтрастна і ехоконтрастна ангіографія.

Ехокардіографія є ультразвуковим дослідженням серця і його судин з визначенням внутрішнього кровотоку. В даний час роздільна здатність ультразвукових приладів дозволяє не лише бачити роботу серця і його структур в реальному масштабі часу, але i розрахувати розміри серця, швидкості кровотоку по магістральних судинах і визначити тиск у порожнинах серця $з$ комп'ютерною обробкою даних. Кольорове доплерівське картування дозволяє швидко визначити просторову орієнтацію потоків.

При підготовці до теоретичної частини заняття студенти використовують методичні вказівки, матеріали підготовки до конкретної теми, які розміщені на вебпорталі університету. Ступінь готовності до заняття кожен студент може перевірити в системі щоденного тестового контролю знань “Moodle”. Студенти позитивно відгукуються про введення цього курсу, що спонукає їх краще осмислити значення медичної техніки i апаратних систем у клінічній практиці, повторити набуті практичні навики. На нашу думку, саме на додипломному рівні навчання сімейного лікаря варто 
прищеплювати студентам прагнення до аналізу нової наукової інформації з використанням всіх сучасних навчальних технологій для одержання оперативних й достовірних даних. У майбутнього фахівця мають сформуватися навички повсякчасної самостійної роботи зі спеціальною літературою, оцінки та раціонального використання наукових повідомлень.

Висновок. Впровадження в навчальний процес на 6 курсі елективного курсу “Медичні апарати i

\section{Література}

1. Ковальчук Л. Я. Новітні шляхи вдосконалення підготовки фахівців у Тернопільському державному медичному університеті імені І. Я. Горбачевського / Л. Я. Ковальчук // Матеріали Всеукраїнської навчально-наукової конференції з міжнародною участю “Впровадження системи" узагальнює знання і навики відносно медичної техніки, засвоєні за період навчання у вузі, $\mathrm{i}$ тим самим підвищує кваліфікаційний рівень підготовки лікаря.

При підготовці сімейного лікаря важливим є формування здатності до критичного аналізу інформації, уміння зіставляти результати досліджень 3 конкретною клінічною ситуацією, враховувати економічні та гуманістичні критеріі.

кредитно-модульної системи організації навчального процесу у ВМ(Ф) НЗ України : результати, проблеми та перспективи". - Тернопіль, 2010.-С. 27-31.

2. Медична техніка / під ред. Г. С. Стеценко. - Луцьк : Надстир'я, 2002.-288 с. 